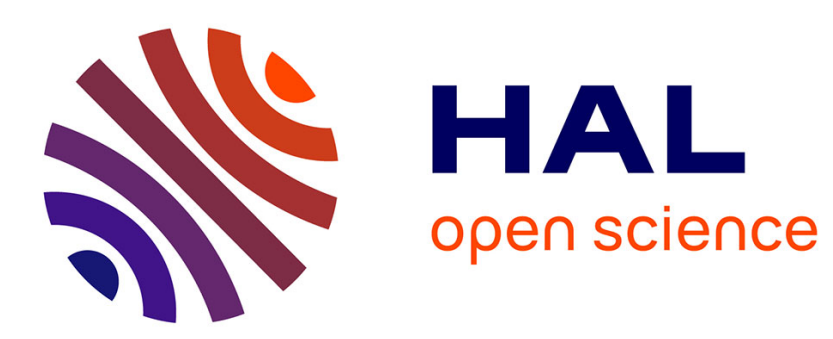

\title{
Correlations between gastropod shell dissolution and water chemical properties in a tropical estuary
}

David J. Marshall, Jose H. Santos, Kenneth M.Y. Leung, Wang H. Chak

\section{To cite this version:}

David J. Marshall, Jose H. Santos, Kenneth M.Y. Leung, Wang H. Chak. Correlations between gastropod shell dissolution and water chemical properties in a tropical estuary. Marine Environmental Research, 2008, 66 (4), pp.422. 10.1016/j.marenvres.2008.07.003 . hal-00563042

\section{HAL Id: hal-00563042 \\ https://hal.science/hal-00563042}

Submitted on 4 Feb 2011

HAL is a multi-disciplinary open access archive for the deposit and dissemination of scientific research documents, whether they are published or not. The documents may come from teaching and research institutions in France or abroad, or from public or private research centers.
L'archive ouverte pluridisciplinaire $\mathbf{H A L}$, est destinée au dépôt et à la diffusion de documents scientifiques de niveau recherche, publiés ou non, émanant des établissements d'enseignement et de recherche français ou étrangers, des laboratoires publics ou privés. 


\section{Accepted Manuscript}

Correlations between gastropod shell dissolution and water chemical properties in a tropical estuary

David J. Marshall, Jose H. Santos, Kenneth M.Y. Leung, Wang H. Chak

PII: S0141-1136(08)00179-7

DOI: 10.1016/j.marenvres.2008.07.003

Reference:

MERE 3269

To appear in:

Marine Environmental Research

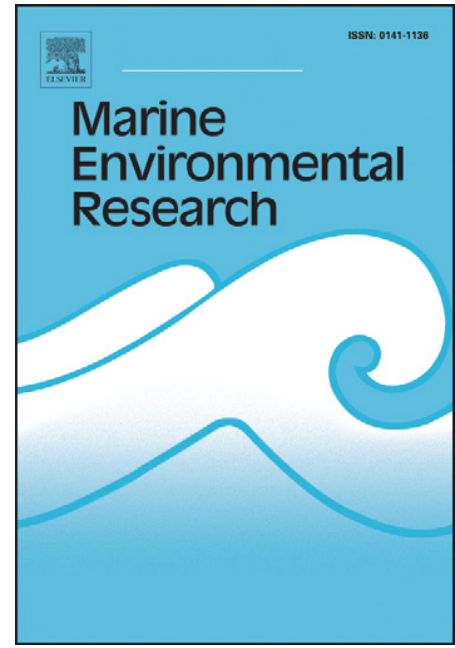

Received Date: $\quad 4$ December 2007

Revised Date: $\quad 3$ July 2008

Accepted Date: $\quad 5$ July 2008

Please cite this article as: Marshall, D.J., Santos, J.H., Leung, K.M.Y., Chak, W.H., Correlations between gastropod shell dissolution and water chemical properties in a tropical estuary, Marine Environmental Research (2008), doi: 10.1016/j.marenvres.2008.07.003

This is a PDF file of an unedited manuscript that has been accepted for publication. As a service to our customers we are providing this early version of the manuscript. The manuscript will undergo copyediting, typesetting, and review of the resulting proof before it is published in its final form. Please note that during the production process errors may be discovered which could affect the content, and all legal disclaimers that apply to the journal pertain. 


\section{Correlations between gastropod shell dissolution and water chemical properties in a tropical estuary}

David J. Marshall ${ }^{\mathrm{a}^{*}}$, Jose H. Santos ${ }^{\mathrm{c}}$, Kenneth M. Y. Leung ${ }^{\mathrm{b}}$ and Wang H. Chak ${ }^{\mathrm{a}}$

${ }^{a}$ Department of Biology, Universiti Brunei Darussalam, Tungku Link, Gadong BE1410, Brunei Darussalam

${ }^{\mathrm{b}}$ The Swire Institute of Marine Science and Division of Ecology \& Biodiversity, School of Biological Sciences, The University of Hong Kong, Pokfulam, Hong Kong, P. R.

China

${ }^{\mathrm{c}}$ Department of Chemistry, Universiti Brunei Darussalam, Tungku Link, Gadong

BE1410, Brunei Darussalam

*Corresponding author:

Dr. David J. Marshall, Department of Biology, Universiti Brunei Darussalam, Tungku Link, Gadong BE 1410, Brunei Darussalam. Telephone: +673-2463001; Fax: +673 2461502; e-mail: marshall@fos.ubd.edu.bn 


\title{
ACCEPTED MANUSCRIPT
}

\begin{abstract}
Although poorly reported in the scientific literature, acidic waters characterize many South East Asian estuaries. The observation of shell dissolution in a typically marine gastropod whelk (Thais) prompted investigation into determining relationships between shell properties of this whelk and the water chemistry (including $\mathrm{pH}$ ) of the Sungai Brunei estuary (Borneo) in which it occurs. Shell weight, shell length and topographical shell features were determined for populations of Thais gradata distributed along a gradient of $\mathrm{pH}$ and salinity ranging between 5.78 and $8.3 \mathrm{pH}$ units, and 3.58 and $31.2 \mathrm{psu}$. Shell weight varied independently of the co-varying acidity, salinity and calcium levels experienced. In contrast, shell length and a semi-quantitative variable based on shell sculpturing (shell erosion rank, SER) were significantly correlated with these water chemistry variables. This study brings attention to the potential use of estuarine organisms and systems in investigating current marine acidification questions.
\end{abstract}

Keywords: Acidification; Calcium carbonate; Estuaries; Gastropods; Thais; $\mathrm{pH}$ 


\section{ACCEPTED MANUSCRIPT}

\section{Introduction}

Acidification of marine systems, notably that relating to elevated atmospheric carbon dioxide $\left(\mathrm{CO}_{2}\right)$ and the oceanic carbonate equilibrium, has attracted considerable recent interest (Broecker, Takahashi, Simpson \& Peng, 1979; Feely, Sabine, Lee, Millero, Lamb, Greeley et al., 2002; Caldeira \& Wickett, 2003; Orr, Fabry, Aumont, Bopp, Doney, Feely et al., 2005). Current prediction of fairly rapid acidification of the ocean surface waters (decades; Orr et al., 2005) is disturbing in the context of our limited understanding of how organisms and ecological systems might respond to this (Seibel \& Walsh, 2003; Pörtner, Langenbuch \& Reipschläger, 2004; Shirayama \& Thornton, 2005). Predictably, organisms with reduced $\mathrm{pH}$ tolerance or with calcium carbonate skeletal structures (such as, coralline algae, corals, echinoderms, molluscs) will be most affected (Pörtner et al., 2004; Jokiel, Rodgers, Kuffner, Andersson, Cox \& Mackenzie, 2008; Kuffner, Andersson, Jokiel, Rodgers \& Mackenzie, 2008; Hall-Spencer, RodolfoMetalpa, Martin, Ransome, Fine, Turner et al., 2008), though community cascading is likely to cause local ecological devastation, especially in the case of coral reef systems (Pelejero, Calvo, McCulloch, Marshall, Gagan, Lough et al., 2005). In the above context, investigations into environmental circumstances leading to carbonate undersaturation and consequently to dissolution of shells and skeletons in marine ecosystems are highly relevant and important.

Although the effects of environmental $\mathrm{CO}_{2}$ and $\mathrm{pH}$ change on organismal functions (growth, physiology and toxicity) are becoming better known (Yamada \& Ikeda, 1999; Hinga, 2002; Seibel \& Walsh, 2003; Michaelidis, Ouzounis, Paleras \& Pörtner, 2005; Shirayama \& Thornton, 2005; Berge, Bjerkeng, Pettersen, Schaanning \& Øxnevad, 2006) information on in situ shell dissolution of oceanic organisms is limited to pelagic pteropod (Clios) and heteropod molluscs (Orr et al., 2005). In littoral systems, 


\section{ACCEPTED MANUSCRIPT}

shell dissolution studies have focused on unicellular foraminiferans which are used to assess current and historical environmental perturbations (Geslin, Debenay, Duleba \& Bonetti, 2002; Hayward, Grenfell, Nicholson, Parker, Wilmhurst, Horrocks et al., 2004). While the above is not necessarily all embracing from an ecological perspective of shell dissolution, only a single known study concerns in situ dissolution for gastropods in coastal systems (Hall-Spencer et al., 2008).

Acidification is generally overlooked in coastal ecological studies, despite its prevalence in estuarine systems (Howland, Tappin, Uncles \& Plummer, 2000; Braga, Bonetti, Burone \& Filho, 2000; Abril, Etcheber, Delille, Frankignoulle \& Borges, 2003; Lin, Wood, Haskins, Ryffel \& Lin, 2004; García-Luque, Forja \& Gómez-Parra, 2005). While lowered salinities reduce the buffering capabilities of estuaries, acidification can derive from high natural and or anthropogenic organic inflows through elevated microbial activity (Mirlean, Baraj, Niencheski, Baisch \& Robinson, 2001; Abril et al., 2003; Braungardt, Achterberg, Elbaz-Poulichet \& Morley, 2003; Lin et al., 2004; Powell \& Martens, 2005, Zai, Dai, Cai, Wang \& Wang, 2005). Heterotrophic microbial metabolism significantly increases acidity through the production of $\mathrm{CO}_{2}$ and carbonic acid in the muddy substratum of estuaries, and in some cases, bacterioplankton may account for $60-100 \%$ of planktonic oxygen consumption (Jonas, 1997). Acidification is exacerbated in turbid eutrophic estuaries as a consequence of reduced photosynthetic activity and biological withdrawal of $\mathrm{CO}_{2}$ (Abril et al., 2003). Although the waters feeding the Sungai Brunei estuary (Brunei Darussalam, Borneo, South East Asia) are naturally acidic, biogenic $\mathrm{CO}_{2}$ production is implied by the combination of extraordinary natural and anthropogenic organic loads, lowered dissolved oxygen levels, elevated dissolved $\mathrm{CO}_{2}$ levels and highly turbid conditions (Chua, Chou \& Sadorra, 1987; DJM, unpublished). 


\section{ACCEPTED MANUSCRIPT}

This study stemmed from the observation of shell dissolution in a gastropod whelk (Thais gradata (Jonas)) which inhabits the Sungai Brunei estuarine system. We aimed to derive relationships between shell dissolution properties of this whelk and water chemical attributes underlying water carbonate saturation of the estuary (particularly $\mathrm{pH}$, calcium and salinity), and to determine which measurable aspects of the shell were most sensitive to dissolution. This study highlights the use of estuarine organisms and estuaries to address acidification questions relating to a broader marine context.

\section{Materials and methods}

\subsection{Estuary and the snails}

The Sungai Brunei estuarine and bay system covers an area of $1380 \mathrm{~km}^{2}$, with the inner bay being fed by several large rivers in Brunei Darussalam (Sungai Brunei and Temburong) and Sarawak, Malaysia (Sungai Limbang and Trusan; Fig. 1; Chua et al., 1987). Waterways are fringed with extensive mangrove stands. The estuary is distinctly brown and turbid, and carries a high organic load deriving from the mangroves and urban centres (Bandar, Kiulap and Gadong; Chua et al., 1987). It has been central to the lifestyles of the Bruneian people for the past four centuries, and currently supports one of the oldest water villages in South East Asia (approximately 29000 people living in stilt houses over the water).

The gastropod whelk, Thais gradata (Jonas) is endemic to southern China and the Malay Archipelago (Tan, 1999). Although typically an inhabitant of mangrove trees, in the Brunei estuary it is highly abundant on artificial embankments and piers, built to retain waters and to facilitate small-craft commutation. A congeneric estuarine species, $T$. malayensis, thought to occur in Sungai Brunei estuary, is distributed across South East Asia and northern Australia (Tan \& Sigurdsson, 1996). 


\section{ACCEPTED MANUSCRIPT}

\subsection{Water chemistry}

Four recording stations were established along the Sungai Brunei estuary, to cover the range of physicochemical conditions that characterize it (Damuan, D, low salinity, 0452'05.6”N, 11454'37.6”E; Bandar, B, low salinity 0453’09.3”N, 11456'53.2”'E; Kota Batu, K, midrange salinity, 04 ${ }^{\circ} 55^{\prime} 42.2^{\prime \prime N}, 115^{\circ} 00^{\prime} 54.3^{\prime \prime} \mathrm{E}$ and Muara, M, high salinity, $05^{\circ} 01^{\prime} 01.1^{\prime \prime} \mathrm{N}, 115^{\circ} 03^{\prime} 57.8^{\prime \prime} \mathrm{E}$; Fig. 1). Water samples were collected from each station on 24 occasions (13 during November 2005 to March 2006 and 11 during August to November 2007). Sampling included a range of tidal conditions and, on any day, all stations were visited in the same order in a $2 \mathrm{~h}$ timeframe. Duplicate air-tight samples (allowing no head space) were collected from the upper $1 \mathrm{~m}$ column adjacent to Thais habitat, using $1000 \mathrm{~mL}$ acid-washed, polythene jars. Samples were returned to the laboratory in $1 \mathrm{~h}$ of completing the sampling series, and were equilibrated at $28^{\circ} \mathrm{C}$ for $1 \mathrm{~h}$ in a Grant constant temperature water-bath. Field water temperature was relatively constant, varying between 27.9 and $33.6^{\circ} \mathrm{C}$ (Fluke thermocouple thermometer 54 II). Salinity and $\mathrm{pH}$ were determined simultaneously at $28^{\circ} \mathrm{C}$; salinity to \pm 0.01 psu (YSI Model $85 \mathrm{D}$ multimeter or $\mathrm{HACH} \mathrm{HQ} 40 \mathrm{~d}$ meter and IntelliCal probe) and $\mathrm{pH}$ to \pm 0.01 units using an NBS scale (Thermo Orion Model 260A or HACH HQ40d calibrated with Mettler Toledo SRM NIST precision buffers). Laboratory measured salinity and $\mathrm{pH}$ were invariable to in situ field measurements taken on five occasions. For the 2007 samples, $100 \mathrm{~mL}$ sub-samples were treated with concentrated nitric acid for calcium analysis. Calcium concentrations of these samples were determined using Shimadzu AA-6701F atomic absorption spectrophotometer in direct injection mode utilising acetylene-air fuel mixture. Total alkalinity was determined for a separate set of samples collected on a single day (27 June 2008, $N=12$ ). Determination involved using potentiometric titration and double-indicator titration employing phenolphthalein and methyl orange indicators. A titrant of standard $\mathrm{HCl}$ 


\section{ACCEPTED MANUSCRIPT}

solution containing $0.7 \mathrm{~mol} \mathrm{~L}^{-1} \mathrm{NaCl}$ was used to adjust the total ionic strength to approximate that of the seawater.

\subsection{Shell weight, shell length and aperture relationships}

Snails $(N=377)$ were collected from four populations (Tamoi, T; Bandar, B; Kota Batu, K and Pulau Bedukang, P; Fig. 1) during July to December 2005. Populations B and K corresponded with the water sampling stations. However, because $\mathrm{T}$ and $\mathrm{P}$ were difficult to access rapidly for water sampling, this was undertaken at nearby stations D (where snails occurred at low abundance) and $\mathrm{M}$ (where no snails occurred; Fig. 1), which showed similar water conditions respectively to those where snails were collected. Snails were haphazardly collected in a manner to include a broad size range. Shells supporting epizoic barnacles were avoided, except population $\mathrm{T}$ which mostly possessed barnacles. Shell scrubbing and removal of epibionts preceded all determinations. To avoid microenvironment effects of mud-bank water, snails were collected from vertical hard substrata, their preferred habitat which drains rapidly during low tides.

Shell length, shell weight, aperture length, and shell structural features were determined in the laboratory. Shell length and aperture length (as a proxy for growth and age) were measured using digital Vernier calipers (precision: $0.01 \mathrm{~mm}$; see Fig. 2). Qualitative features of the shells were assessed by a method described below. Shells were then cracked open with a bench vice to separate shell material from the tissue, and the shell material was dried at $60^{\circ} \mathrm{C}$ for $3 \mathrm{~d}$ to achieve a constant weight, determined to 0.001 g with a Mettler Toledo PB303. We determined how shell weight and shell length were related to aperture length and, whether and how the populations differed with respect to these relationships (General Linear Models, Statistica Version 6, Statsoft Inc.). Because preliminary observations showed that smaller shells elongate more rapidly while 


\section{ACCEPTED MANUSCRIPT}

remaining thin, causing a non-linear shell weight to shell elongation relationship, shells having an aperture shorter than $15 \mathrm{~mm}$ long were excluded from the analyses. Each model comprised a categorical predictor (snail population with four levels; T, B, K and P), a dependent variable (shell weight or shell length), and continuous variable (aperture). All regressions conformed to assumptions of normality, heteroscedasticity, and homogeneity of variance (Cochran's test).

\subsection{Shell erosion rank (SER)}

The surface of non-eroded Thais shells is characterized by an outer periostracum growing over fine axial riblets which interconnect with spiral riblets to form cancellate patterning (axial riblets and the periostracum are not readily discernible in Fig. 2). Dissolution causes the sequential loss of these features in the above order. Because the apex (being the oldest part of the shell) is always eroded and the outer lip (comprising the most recently deposited shell) is usually intact, these parts were excluded from the shell assessment. Extreme dissolution leads to smoothing of the shell (loss of periostracum, axial riblets and spiral riblets) and rounding of the apex, longitudinal ribs (or spines) and whorl shoulders (Fig. 2c and 2f). Although Tan \& Sigurdsson (1996) suggested that the development of spines is individually variable, spines were conspicuous in all individuals of population $\mathrm{P}$ (Fig. 2).

Each snail was ranked according to the following criteria. Rank 1 (non-erosion): periostracum and axial riblets distinct on most of the shell, and longitudinal ribs on spire whorls, pronounced (Fig. 2a and 2d). Rank 2: longitudinal ribs on spire whorls, eroded and indistinct; spiral and axial riblets on body whorl adjacent to the parietal lip, distinct

(Fig. 2b and 2e). Rank 3: axial and spiral riblets directly adjacent to parietal lip eroded, but conspicuous elsewhere on the body whorl (especially on the surface opposite the 


\section{ACCEPTED MANUSCRIPT}

aperture, not shown in figure). Rank 4: axial and spiral riblets eroded on entire body whorl (Fig. 2c and 2f). Aperture length, as an assessment of size, was determined along with the SER for each shell for $N=33$ for each population. Because very small shells had experienced limited acidic exposure, only shells $>20 \mathrm{~mm}$ were used in SER determinations.

\section{Results}

\subsection{Water chemistry determinations}

The stations differed markedly in $\mathrm{pH}$, salinity and calcium regime; mean values showed a decreasing trend from the seaward to the landward stations (Stn. $M>K>B \geq D$; Table 1). $\mathrm{pH}$ varied between 5.78 and 8.3 units and salinity between 3.8 and $31.2 \mathrm{psu}$, with lowest and highest values for each variable recorded at stations B and $\mathrm{M}$, respectively (Table 1). The water chemistry was most variable at B and least variable at $\mathrm{M}$ (Table 1). Relationships for the water chemical variables are: $\mathrm{pH}=4.10+2.62 \log 10$ salinity; calcium $=21.25+12.65$ salinity; $\mathrm{R}^{2}=0.89, P<0.001 ;$ Fig. 3$)$. The spatial pattern of water chemistry was consistent across stations $(\mathrm{M}>\mathrm{K}>\mathrm{B} \geq \mathrm{D})$ on each recording session, but varied temporally on different days in relation to tidal flux and rainfall events (Fig. 3). Preliminary data showed that total alkalinity was related to salinity as follows: total alkalinity $\left(\mathrm{mmol} . \mathrm{L}^{-1}\right)=0.884+0.033$ salinity $(\mathrm{psu}), \mathrm{R}^{2}=0.94, P<0.001$.

\subsection{Shell weight, shell length and aperture relationships}

Relationships for shell weight against aperture length differed significantly among populations; the landward populations generally had heavier shells (Fig. 4a; Table 2). Shell length as a function of aperture also differed among the populations, with shorter shells found in the landward populations, for the range of shell sizes examined (Fig. 4b; 


\section{ACCEPTED MANUSCRIPT}

Table 2). The effect of size was removed by scaling data to a standard aperture length $(S A L)$ using the slope coefficient $(b)$ for the individual regressions (see Fig. 4) as follows (see Packard \& Boardman, 1988):

Standard shell weight $($ or shell length $)=(S A L / \text { aperture length })^{b} \times$ shell weight $($ or shell length)

$S A L$ is the grand mean for aperture length, which for shell weight $=19.1 \mathrm{~mm}$ and for shell length $=18.9 \mathrm{~mm}$. Standardized shell weight was not significantly different between populations $\mathrm{B}, \mathrm{K}$ and $\mathrm{P}$, but $\mathrm{T}$ was significantly greater than the others (Fig. 5). However, standardized shell length increased progressively across populations, from landward to seaward (Fig. 5). Population $\mathrm{T}$ thus comprises snails possessing not only the heaviest shells, but also the shortest shells (Fig. 5). Significant positive correlations were found for means of standard shell length against estuarine $\mathrm{pH}$ and calcium $(\mathrm{pH}=-2.25+0.36$ shell length, $\mathrm{R}^{2}=0.96, P=0.022$; calcium $=-865.32+43.09$ shell length, $\mathrm{R}^{2}=0.95, P=$ 0.027; Fig. 5c).

\subsection{Shell erosion rank (SER)}

Shell erosion rank (SER) differed strikingly among the populations, with the landward populations ( $\mathrm{T}$ and $\mathrm{B}$ ) scoring much higher than the seaward populations ( $\mathrm{K}$ and $\mathrm{P}$; Fig. 6a). There was no significant difference between populations T and B (Fig. 6a). Shells from population $\mathrm{P}$ showed little dissolution effect (Fig. 2). Furthermore, SER was independent of aperture length, for shell lengths $>20 \mathrm{~mm}$ (Fig. 6b). SER was negatively related to estuarine water $\mathrm{pH}\left(\mathrm{pH}=8.52-0.55 \mathrm{SER} ; \mathrm{R}^{2}=0.98, P=0.008\right)$ and calcium concentration $\left(\right.$ calcium $=431-66.6 \mathrm{SER}, \mathrm{R}^{2}=0.97, P=0.014$; Fig. $6 \mathrm{c}$ ). 


\section{ACCEPTED MANUSCRIPT}

\section{Discussion}

Acidification has not received the same consideration in estuarine ecology as have processes involving other physicochemical variables (temperature, salinity and hypoxia), despite its implied effect on the structuring and functioning of estuarine systems (Knutzen, 1981; Diaz \& Rosenburg, 1995; Burnett, 1997; Ringwood \& Keppler, 2002). Relevant studies on estuarine acidification mostly concern spatial and temporal patterns of the water chemistry and not biological effects (Howland et al., 2000; Mirlean et al., 2001; Braungardt et al., 2003; Jennerjahn, Ittekkot, Klöpper, Adi, Nugroho, Sudiana et al., 2004; Lin et al., 2004; García-Luque et al., 2005). We recorded the predictable pattern of a declining landward gradient in $\mathrm{pH}$, salinity and calcium concentration in the Sungai Brunei estuary (Fig. 3). Although the water chemistry at any station was temporally variable in relation to tidal flux and local rainstorm events, shell dissolution in populations of Thais gradata correlated with the average $\mathrm{pH}$ and calcium concentration experienced (Figs. 5 and 6). While these correlations suggest the potential for using shell dissolution to capture the effects of highly variable estuarine water chemistry, dissolution is caused by carbonate undersaturation, and determination of the water carbonate saturation state $(\Omega)$ at the various stations in relation to the measured chemical parameters would be required for a complete interpretation. Saturation state is however expected to closely track the observed variation in $\mathrm{pH}$ (see Kuffner et al., 2008).

Acidification of the Sungai Brunei estuary seems primarily to arise from the combination of natural and anthropogenic eutrophication and heterotrophic metabolism. Although acidic freshwater inflows characterize the system (Chua et al., 1987), significant biogenic carbonic acid production due to mangrove bacterial decomposition must affect the landward stations of the estuary (see Braga et al., 2000; Abril et al., 2003). Similar $\mathrm{pH}$ levels at stations D and B, despite the more seaward location of B, 


\section{ACCEPTED MANUSCRIPT}

suggests acidic priming from the major urbanized areas via Sungai Kedayang (Fig. 1).

Raw and treated sewage enters the system near station B from the water village Kampong Ayer, and downstream of station B from Pintu Malim, the largest sewage treatment plant in the country. Acidification through heterotrophic metabolism is further implied by elevated dissolved carbon dioxide and lowered dissolved oxygen levels at the landward stations (Chua et al, 1987; DJM, unpublished data). Seaward increases in $\mathrm{pH}$ results from buffering and increased hardness of the more saline waters (Mirlean et al., 2001; GarcíaLuque et al., 2005). Although water chemistry $(\mathrm{pH}$, carbonate saturation state and alkalinity) commonly varies dielly in coastal systems in relation to net $\mathrm{CO}_{2}$ production by primary producers (Kuffner et al., 2008), we presume that this effect is reduced by the highly turbid conditions that characterize this system and is probably masked by rainfall events and tidal flow patterns.

The three shell variables assessed (shell weight, shell length, and shell erosion rank) differed in sensitivity to the measured conditions underlying dissolution $(\mathrm{pH}$ and calcium concentration). While shell length and shell surface sculpturing (SER) varied among populations in a predictable way, shell weight was contrary to the prediction (Figs. 4, 5 and 6). Snails exposed to higher acidity levels sometimes possessed heavier shells (populations $\mathrm{T}>\mathrm{B}=\mathrm{K}=\mathrm{P}$; Fig. 5), suggesting that factors other than dissolution influence shell weight loss or gain in field populations. Theoretically, several intrinsic factors may affect shell production or shell weight loss under these circumstances. For example, internal shell dissolution contributes to regulating $\mathrm{pH}$ of the extracellular fluids in many shellfish experiencing acidic conditions (Michaelidis et al., 2005). On the other hand, gastropod shell production is affected by nutritional state, organismal growth rate, and even predation pressure. Slower growth rates due to constrained feeding are known to cause shell thickening in congeners of this species (Palmer, 1981), and the possibility 


\section{ACCEPTED MANUSCRIPT}

exists for reduced food availability at the more acidic localities. Moreover, congeners are known to induce shell production under predation pressure (Palmer, 1981; Appleton and Palmer, 1988; Palmer 1992), though it is unknown how populations of predatory crabs vary spatially in the Sungai Brunei estuary. It is further possible that snails of the heavilyshelled Tamoi population induce shell production in response to epibiont colonization, or as a consequence of shell thinning detected through proprioception (but see Bibby, Cleall-Harding, Rundle, Widdicombe \& Spicer, 2007). In contrast, dissolution of external shell features and erosion of the apex (causing shortening) are largely independent of the intrinsic factors affecting shell weight. Furthermore, the capacity to increase calcification under increased acidity has been recently shown in brittlestars (Wood, Spicer \& Widdicombe, 2008).

The absence of previous reports raises the question on how widespread gastropod shell dissolution in estuaries actually is. Does this represent a low incidence of estuarine acidification, is it more typical to the lesser studied tropical estuaries, or is it particular of estuarine-dwelling Thais snails? A few published studies, including from South East Asia (Jennerjahn et al., 2004; Zai, Dai, Cai, Wang \& Wang, 2005), show that common features of estuarine acidification include high turbidity, eutrophication and heavy rainfall events (Abril, et al., 2003; Paquay, Mackenzie \& Borges, 2006). Nonetheless, the structural and mineralogical properties of Thais shells suggest a relatively high potential for dissolution. These shells are typically aragonitic and lack the outer slower-dissolving calcitic layer found in some gastropods (Cubillas et al., 2005), notwithstanding other influences of dissolution such as crystal size and the proportion of organic matrix in the shell (Harper, 2000). The global distribution of snails that possess these kinds of shells and live in estuaries characterized by acidification is unknown. We assume that the visible absence of shell dissolution in a variety of littorinid and neritid snails which cohabit with $T$. 


\section{ACCEPTED MANUSCRIPT}

gradata in the Sungai Brunei estuary relates to the combination of different shell properties and their more upper-shore distributions, exposing them relatively infrequently to the acidic water.

Aside from their shell properties, Thais snails contrast markedly with other marine organisms in physiological ability to tolerate and grow under highly variable and extreme acidic conditions (Hall-Spencer et al., 2008 give recent data on field acidity conditions supporting other coastal gastropods). Studies examining acidity tolerances of marine animals have however mainly concerned plankton and bivalve molluscs (Knutzen, 1981; Bamber, 1990; Yamada \& Ikeda, 1999; Hinga, 2002; Ringwood \& Keppler, 2002; Michaelidis et al., 2005; Sato, Watanabe, Toyota \& Ishizaka, 2005; Berge et al., 2006). Growth rates of bivalves are impeded by increasing acidity down to $6.7 \mathrm{pH}$ units when all growth ceases, and significant mortality occurs at around $6.0 \mathrm{pH}$ units (Bamber, 1990; Michaeldis et al., 2005; Berge et al., 2006). Oceanic copepods are even more limited in their tolerance of acidification and die when exposed to a reduction of only $0.2 \mathrm{pH}$ units (Seibel \& Walsh, 2003). In view of the likelihood of their evolutionary historical association with acidic conditions, Thais gradata could serve as a model system to understanding mechanisms for survival of elevated $\mathrm{CO}_{2}$ and acidity, including behavioral isolation, and physiological acclimation and adaptation. This study further highlights the potential for using estuaries in understanding the consequences of marine acidification in general.

\section{Acknowledgements}

Research grant funding to DJM was provided through the Ministry of Development (MOD), Brunei Darussalam. Kamal Ariffin and Mohammad Amad are thanked for 


\section{ACCEPTED MANUSCRIPT}

technical support and data provision. The comments of two anonymous referees lead to an improved version of the manuscript.

\section{References}

Abril, G., Etcheber, H., Delille, B., Frankignoulle, M., \& Borges, A.V. (2003). Carbonate dissolution in the turbid and eutrophic Loire estuary. Marine Ecology Progress Series, 259, 129-138.

Appleton, R.D., \& Palmer, A.R. (1988). Water-borne stimuli released by predatory crabs and damaged prey induce more predator-resistant shells in a marine gastropod. Proceedings of the National Academy of Sciences (USA), 85, 4387-4391.

Bamber, R.N. (1990). The effects of acidic seawater on three species of lamellibranch mollusc. Journal of Experimental Marine Biology and Ecology, 143, 181-191.

Berge, J.A., Bjerkeng, B., Pettersen, O., Schaanning, M.T., \& Øxnevad, S. (2006). Effects of increased seawater concentrations of $\mathrm{CO}_{2}$ on growth of the bivalve Mytilus edulis L. Chemosphere, 62, 681-687.

Bibby, R., Cleall-Harding, P., Rundle, S., Widdicombe, S., \& Spicer, J. (2007). Ocean acidification disrupts induced defences in the intertidal gastropod Littorina littorea. Biology Letters, doi:10.1098/rsbl.2007.0457

Braga, E.S., Bonetti, C.V.D.H., Burone, L., \& Filho, J.B. (2000). Eutrophication and bacterial pollution caused by industrial and domestic wastes at the Baixada Santista estuarine system - Brazil. Marine Pollution Bulletin, 40, 165-173.

Braungardt, C.B., Achterberg, E.P, Elbaz-Poulichet, F., \& Morley, N.H. (2003). Metal geochemistry in a mine-polluted estuarine system in Spain. Applied Geochemistry, 18, 1757-1771.

Broecker, W.S., Takahashi, T., Simpson, H.J. \& Peng, T-H. (1979). Fate of fossil fuel carbon dioxide and the global carbon budget. Science, 206, 409-418. 


\section{ACCEPTED MANUSCRIPT}

Burnett, L.E. (1997). The challenges of living in hypoxic and hypercapnic aquatic environments. American Zoologist, 37, 633-640.

Caldeira, K. \& Wickett, M.E. (2003). Oceanography: Anthropogenic carbon and ocean pH. Nature, 425, 365.

Chua, T-E., Chou, L.M., \& Sadorra, M.S.M. (1987). The coastal environmental profile of Brunei Darusslam: Resource assessment and management issues. ICLARM Technical Report 18, Fisheries Department, Ministry of Development, Brunei Darussalam.

Cubillas, P., Köhler, S., Prieto, M., Chaïrat, C., \& Oelkers, E.H. (2005). Experimental determination of the dissolution rates of calcite, aragonite, and bivalves. Chemical Geology, 216, 59-77.

Diaz, R.J., \& Rosenburg, R. (1995). Marine benthic hypoxia: A review of its ecological effects and the behavioral responses of benthic macrofauna. Oceanography and Marine Biology Annual Review, 33, 245-303.

Feely, R.A., Sabine, C.L., Lee, K., Millero, F.J., Lamb, M.F., Greeley, D., Bullister, J.L., Key, R.M., Peng, T-H., Kozyr, A., Ono, T., \& Wong, C.S. (2002). In situ calcium carbonate dissolution in the Pacific Ocean. Global Biochemical Cycles, 16, 1144, doi:10.1029/2002GB001866.

García-Luque, E., Forja, J.M., \& Gómez-Parra, A. (2005). Characterization of atmosphere-water exchange processes of $\mathrm{CO}_{2}$ in estuaries using dynamic simulation. Journal of Marine Systems, 58, 98-106.

Geslin, E., Debenay, J-P., Duleba, W., \& Bonetti, C. (2002). Morphological abnormalities of foraminiferal tests in Brazilian environments: comparison between polluted and non-polluted areas. Marine Micropaleontology, 45, 151168. 
Hall-Spencer, J.M., Rodolfo-Metalpa, R., Martin, S., Ransome, E., Fine, M., Turner, S.M., Rowley, S.J., Tedesco, D. \& Buia, M-C. (2008). Volcanic carbon dioxide vents show ecosystem effects of ocean acidification. Nature, doi:10.1038/nature07051.

Harper, E.M. (2000). Are calcitic layers an effective adaptation against shell dissolution in the Bivalvia? Journal of Zoology, 251, 179-186.

Hayward, B.W., Grenfell, H.R., Nicholson, K., Parker, R., Wilmhurst, J., Horrocks, M., Swales, A., \& Sabaa, A.T. (2004). Foraminiferal record of human impact on intertidal estuarine environments in New Zealand's largest city. Marine Micropaleontology, 53, 37-66.

Hinga, K.R. (2002). Effects of $\mathrm{pH}$ on coastal marine phytoplankton. Marine Ecology Progress Series, 238, 218-300.

Howland, R.J.M., Tappin, A.D., Uncles, R.J., \& Plummer, D.H. (2000). Distributions and seasonal variability of $\mathrm{pH}$ and alkalinity in the Tweed Estuary, UK. The Science of the Total Environment, 251, 125-138.

Jennerjahn, T.C., Ittekkot, V., Klöpper, S., Adi, S., Nugroho, S. P., Sudiana, N., Yusmal, A., Prihartano, \& Gaye-Haake, B. (2004). Biogeochemistry of a tropical river affected by human activities in its catchment: Brantas River estuary and coastal waters of Mandura Strait, Java, Indonesia. Estuarine, Coastal and Shelf Science, $60,503-514$.

Jokiel, P.L., Rodgers, K.S., Kuffner, I.B., Andersson, A.J., Cox, E.F., \& Mackenzie, F.T. (2008). Ocean acidification and calcifying reef organisms: a mesocosm investigation. Coral Reefs, doi: 10.1007/s00338-008-0380-9 


\section{ACCEPTED MANUSCRIPT}

Jonas, R.B. (1997). Bacteria, dissolved organics and oxygen consumption in salinity stratified Chesapeake Bay, an anoxia paradigm. American Zoologist, 37, 612-620.

Knutzen, J. (1981). Effects of decreased $\mathrm{pH}$ on marine organisms. Marine Pollution Bulletin, 12, 25-29.

Kuffner, I.B., Andersson, A.J., Jokiel, P.L., Rodgers, K.S., \& Mackenzie, F.T. (2008). Decreased abundance of crustose coralline algae due to ocean acidification. Nature Geoscience, doi:10.1038/ngeo100.

Lin, C., Wood, M., Haskins, P., Ryffel, T., \& Lin, J. (2004). Controls on water acidification and deoxygenation in an estuarine waterway, eastern Australia. Estuarine, Coastal and Shelf Science, 61, 55-63.

Michaelidis, B., Ouzounis, C., Paleras, A., \& Pörtner, H.O. (2005). Effects of long-term moderate hypercapnia on acid-base balance and growth rate in marine mussels Mytilus galloprovincialis. Marine Ecology Progress Series, 293, 109-118.

Mirlean, N., Baraj, B., Niencheski, L.F., Baisch, P., \& Robinson, D. (2001). The effect of accidental sulphuric acid leaking on metal distributions in estuarine sediment of Patos Lagoon. Marine Pollution Bulletin, 42, 1114-1117.

Orr, J.C., Fabry, V.J., Aumont, O., Bopp, L., Doney, S.C., Feely, R.A., Gnanadesikan, A., Gruber, N., Ishida, A., Joos, F., Key, R.M., Lindsay, K., Maier-Reimer, E., Matear, R., Monfray, P., Mouchet, A., Najjar, R.G., Plattner, G-K., Rodgers, K.B., Sabine, C.L., Sarmiento, J.L., Schlitzer, R., Slater, R.D., Totterdell, I.J., Weirig, M-F., Yamanaka, Y., \& Yool, A. (2005). Anthropogenic ocean acidification over the twenty-first century and its impact on calcifying organisms. Nature, 437, 681-686.

Packard, G.C., \& Boardman, T.J. (1988). The misuse of ratios, indicies and percentages in ecophysiological research. Physiological Zoology, 61, 109. 


\section{ACCEPTED MANUSCRIPT}

Palmer, A.R. (1981) Do carbonate skeletons limit the rate of body growth? Nature, 292, $150-152$.

Palmer, A.R. (1992). Calcification in marine molluscs: How costly is it? Proceedings of the National Academy of Sciences (USA), 89, 1379-1382.

Paquay, F.S., Mackenzie, F.T., \& Borges, A.V. (2006). Carbon dioxide dynamics in rivers and coastal waters of the "big island" of Hawaii, USA, during baseline and heavy rain conditions. Aquatic Geochemistry, doi 10.1007/s10498-006-9005-5.

Pörtner, H.O., Langenbuch, M., \& Reipschläger, A. (2004). Biological impact of elevated ocean $\mathrm{CO}_{2}$ concentrations: lessons from animal physiology and earth history. Journal of Oceanography, 60, 705-718

Pörtner, H.O., Langenbuch, M., \& Michaelidis, B. (2005). Synergistic effects of temperature extremes, hypoxia, and increases in $\mathrm{CO}_{2}$ on marine animals: From Earth history to global change. Journal of Geophysical Research, 110, C09S10, doi 10.1029/2004JC002561.

Powell, B., \& Martens, M. (2005). A review of acid sulfate soil impacts, actions and policies that impact on water quality in Great Barrier Reef catchments, including a case study on remediation at East Trinity. Marine Pollution Bulletin, 51, 149164.

Pelejero, C., Calvo, E., McCulloch, M.T., Marshall, J.F., Gagan, M.K., Lough, J.M., \& Opdyke, B.N. (2005). Ocean Science: preindustrial to modern interdecadal variability in coral reef pH. Science, 309, 2204-2207.

Ringwood, A.H., \& Keppler, C.J. (2002). Water quality variation and clam growth: Is pH really a non-issue in estuaries? Estuaries, 25, 901-907. 


\section{ACCEPTED MANUSCRIPT}

Sato, T., Watanabe, Y., Toyota, K., \& Ishizaka, J. (2005). Extended probit mortality model for zooplankton against transient change of $\mathrm{PCO}_{2}$. Marine Pollution Bulletin, 50, 975-979.

Shirayama, Y., \& Thornton, H. (2005). Effect of increased atmospheric $\mathrm{CO}_{2}$ on shallow water marine benthos. Journal of Geophysical Research C: Oceans, 110, 1-7.

Seibel, B.A., \& Walsh, P.J. (2003). Biological impacts of deep-sea carbon dioxide injection inferred from indices of physiological performance. Journal of Experimental Biology, 206, 641-650.

Tan, K.S., \& Sigurdsson, J.B. (1996). New species of Thais (Neogastropoda, Muricidae) from Singapore, with a re-description of Thais javanica (Philippi, 1848). Journal of Molluscan Studies, 62, 517-535.

Tan, K.S. (1999). Imposex in Thais gradata and Chicoreus capucinus (Mollusca, Neogastropoda, Muricidae) from the Straits of Johor: A case study using penis length, area, and weight as measures of imposex severity. Marine Pollution Bulletin, 39, 295-303.

Yamada, Y., \& Ikeda, T. (1999). Acute toxicity of lowered pH to some zooplankton. Plankton Biology and Ecology, 46, 62-67.

Wood, H.L., Spicer, J.I., \& Widdicombe, S. (2008). Ocean acidification may increase calcification rates, but at a cost. Proceedings of the Royal Society B, 275, 17671773.

Zai, W., Dai, M., Cai, W-J., Wang, Y., \& Wang, Z. (2005). High partial pressure of $\mathrm{CO}_{2}$ and its maintaining mechanism in a subtropical estuary: the Pearl River estuary, China. Marine Chemistry, 93, 21-32. 


\section{ACCEPTED MANUSCRIPT}

\section{Figure captions}

Fig. 1. Map of Brunei bay and the Sungai Brunei estuary. Sampling stations are D, Damuan; T, Tamoi; B, Bandar; K, Kota Batu; P, Pulau Bedukang; M, Muara and $k l$, Sungai Kedayang.

Fig. 2. Thais gradata shells from the Sungai Brunei estuary, showing different dissolution effects. Side and apical views of shells from (a, d) Pulau Bedukang (P), (b, e) Kota Batu (K), and (c, f) Bandar (B), respectively indicating shell dissolution ranks (SERs) 1, 2 and 4 (see text for further details). Abbreviations are as follows: $s l$, shell length; $a l$, aperture length; $r s$, spiral riblets, $r l$; longitudinal ribs; $p l$, parietal lip and $o l$, outer lip. Scale bar for (a), (b) and (c) indicates $10 \mathrm{~mm}$, and that for (d), (e) and (f) indicates $20 \mathrm{~mm}$.

Fig. 3. Relationships between salinity, $\mathrm{pH}$ and calcium concentration in the Sungai Brunei estuary. (a) pH against salinity; Muara (open circles); Kota Batu (closed circles); Damuan (triangles) and Bandar (squares).

Fig. 4. Relationships between aperture length, shell length and shell weight of the four populations of Thais gradata from the Sungai Brunei estuary. T, Tamoi; B, Bandar; K, Kota Batu; P, Pulau Bedakang. Regression equations are indicated in figure; $P<0.001$. (a) Shell weight against aperture length; line $\mathrm{B}$ is omitted for clarity. (b) Shell length against aperture length; line $\mathrm{T}$ is omitted for clarity. Statistical analyses are given in Table 2.

Fig. 5. Means $\pm 95 \%$ C.I. for (a) standardized shell weight $\left(\chi^{2}=13.4\right.$, df $\left.=3, P=0.038\right)$ and (b) standardized shell length $\left(\chi^{2}=57.07, d f=3, P<0.001\right)$. T, Tamoi; B, Bandar; K, Kota Batu; P, Pulau Bedukang. Number in parenthesis indicates sample size. (c) Mean standardized shell length against means for $\mathrm{pH}$ (circles, thick line) and calcium (squares, thin line; see Fig. 4 and Tables 1, 2). 
Fig. 6. Means $\pm 95 \%$ C.I. for (a) shell erosion rank $\left(\mathrm{F}_{3,128}=89.95, P<0.001\right)$ and (b) aperture length $\left(\chi^{2}=15.87, d f=3, P=0.0012\right)$ using the same snails $(N=33)$ for each population. T, Tamoi; B, Bandar; K, Kota Batu; P, Pulau Bedukang. Significant differences in (a) are indicated by different letters associated with error bars. (c) Mean shell erosion rank (SER) against mean $\mathrm{pH}$ (circles, thick line) and calcium (squares, thin line; see Table 1). 
Table 1. Descriptive statistics for $\mathbf{p H}$, salinity and Ca for each station

\begin{tabular}{llllll}
\hline & Station & Mean \pm SD & Max & Min & $N$ \\
& & & & \\
pH & D & $6.80 \pm 0.23$ & 7.11 & 6.33 & 22 \\
& B & $6.83 \pm 0.39$ & 7.51 & 5.78 & 24 \\
& K & $7.44 \pm 0.43$ & 8.09 & 6.5 & 23 \\
& M & $8.02 \pm 0.15$ & 8.3 & 7.73 & 24 \\
Salinity & D & $12.25 \pm 4.27$ & 19.56 & 5.32 & 22 \\
(psu) & B & $13.50 \pm 5.49$ & 22.7 & 3.58 & 24 \\
& K & $18.47 \pm 4.89$ & 26.9 & 9.5 & 23 \\
& M & $27.16 \pm 3.0$ & 31.2 & 19.6 & 25 \\
Calcium & D & $227.9 \pm 55.7$ & 296 & 111 & 11 \\
$($ ppm) & B & $226.2 \pm 85.9$ & 333 & 43 & 11 \\
& $\mathrm{C}$ & $292.5 \pm 50.4$ & 374 & 209 & 11 \\
& $\mathrm{D}$ & $374.6 \pm 47.1$ & 427 & 280 & 11 \\
\hline
\end{tabular}

$\mathrm{D}$ = Damuan; $\mathrm{B}=$ Bandar; $\mathrm{K}=$ Kota Batu; $\mathrm{M}=$ Muara 
Table 2. Statistical analyses of General Linear Models for shell weight and shell length against aperture of the four populations of Thais gradata in the Sungai Brunei estuary (see Fig. 4)

\begin{tabular}{|c|c|c|c|c|c|}
\hline & SS & $d f$ & MS & & $P$ \\
\hline \multicolumn{6}{|c|}{ Shell weight versus aperture length (Fig. 4a) } \\
\hline Intercept & 47.3 & 1 & 47.3 & 337.82 & $<0.0001$ \\
\hline Aperture length & 99.8 & 1 & 99.8 & 712.91 & $<0.0001$ \\
\hline Population & 10.9 & 3 & 3.6 & 26.04 & $<0.0001$ \\
\hline Error & 16.2 & 116 & 0.14 & & \\
\hline \multicolumn{6}{|c|}{ Shell length versus aperture length (Fig. 4b) } \\
\hline Intercept & 5.03 & 1 & 5.03 & 4.86 & 0.028 \\
\hline Aperture length & 4113.8 & 1 & 4113.8 & 3974.89 & $<0.0001$ \\
\hline Population & 113.4 & 3 & 44.46 & 42.96 & $<0.0001$ \\
\hline Error & 384.99 & 372 & 1.04 & & \\
\hline
\end{tabular}

Comparisons of population relationships for shell weight against aperture length are: $\mathrm{T}=\mathrm{B}$ but $\neq \mathrm{K}$ and $\mathrm{P} ; \mathrm{B}=\mathrm{K}$ but $\neq \mathrm{P} ; \mathrm{K} \neq \mathrm{P} ; P<$ 0.01 and for shell length against aperture length are: $\mathrm{T}=\mathrm{B}$ and $\mathrm{K}$ but $\neq \mathrm{P} ; \mathrm{B} \neq \mathrm{K}$ and $\mathrm{P} ; \mathrm{K} \neq \mathrm{P} ; P<0.01$. 


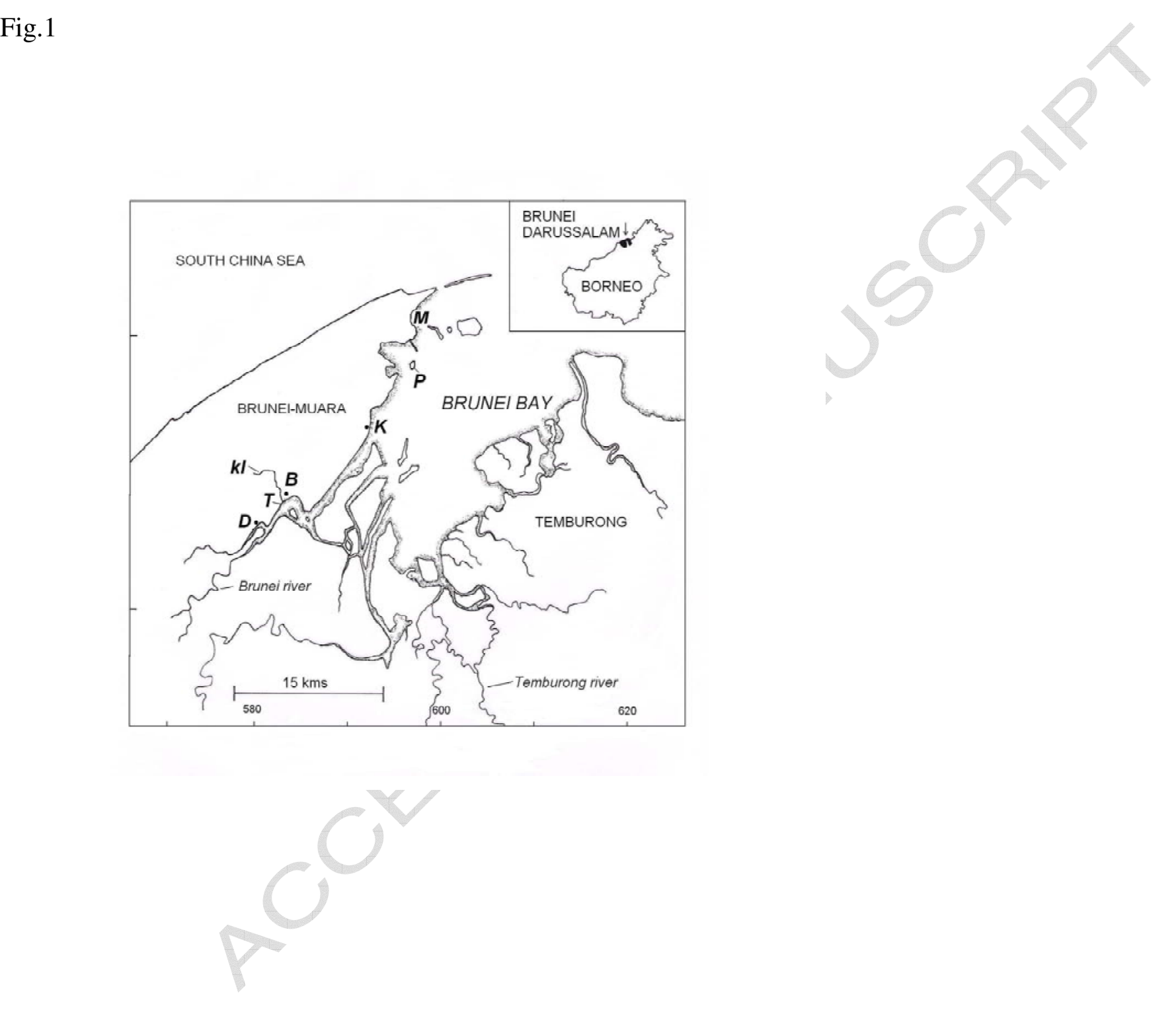



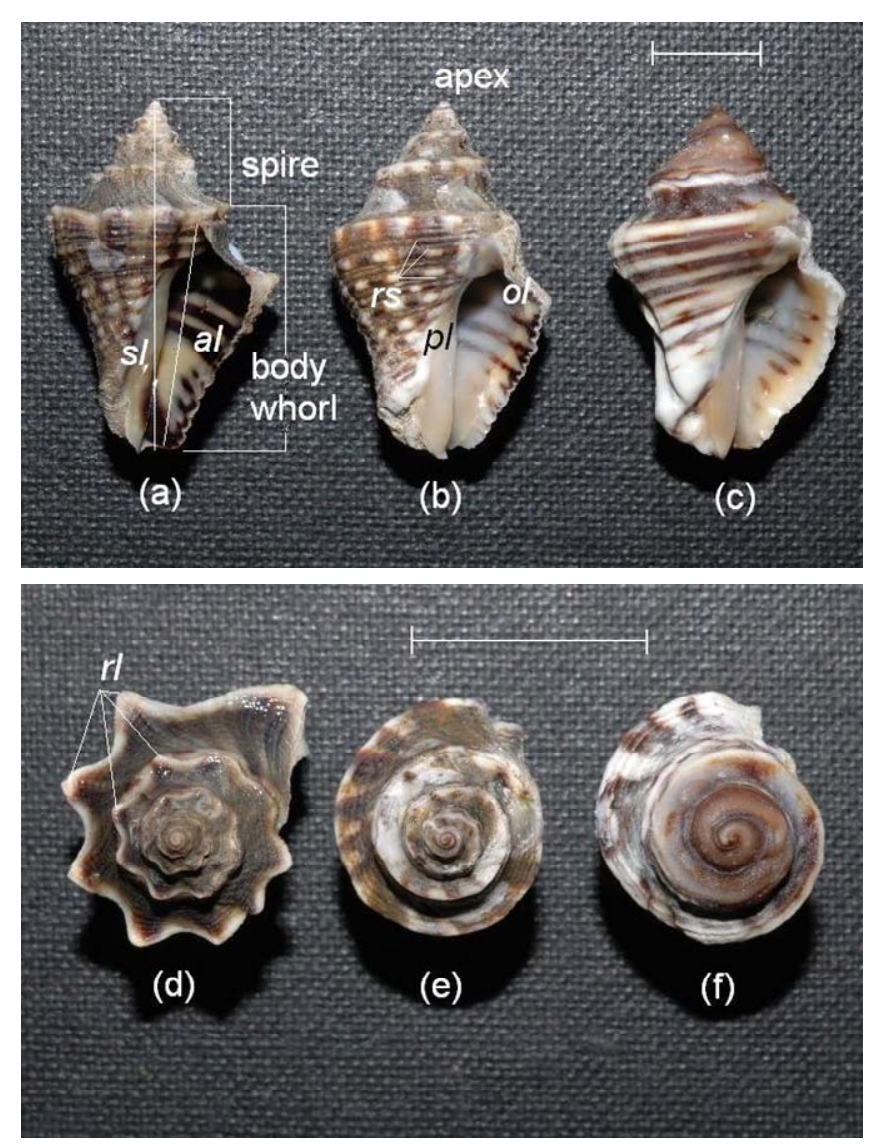

Fig.2 


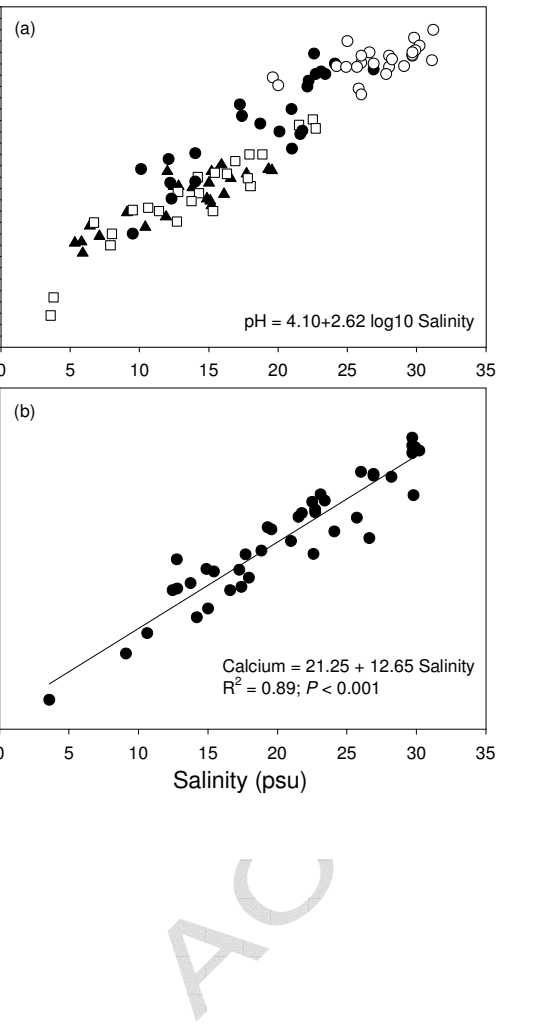


Fig.4

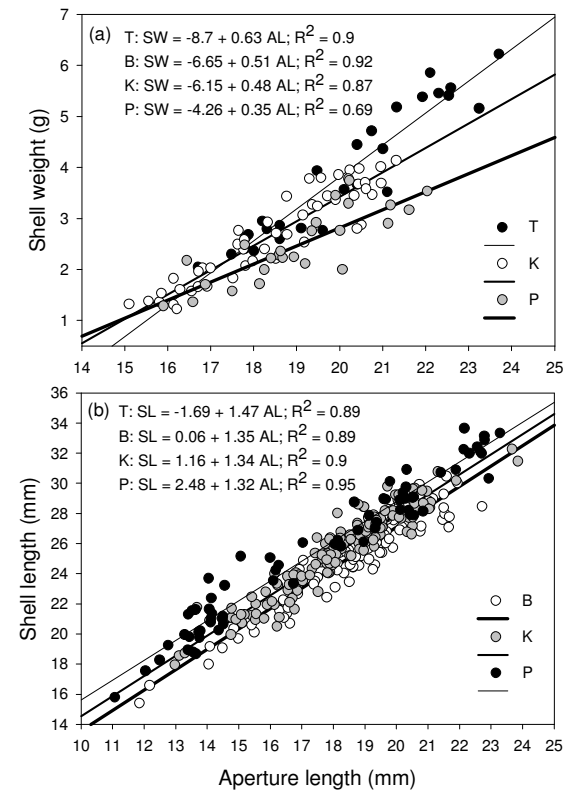


Fig.5
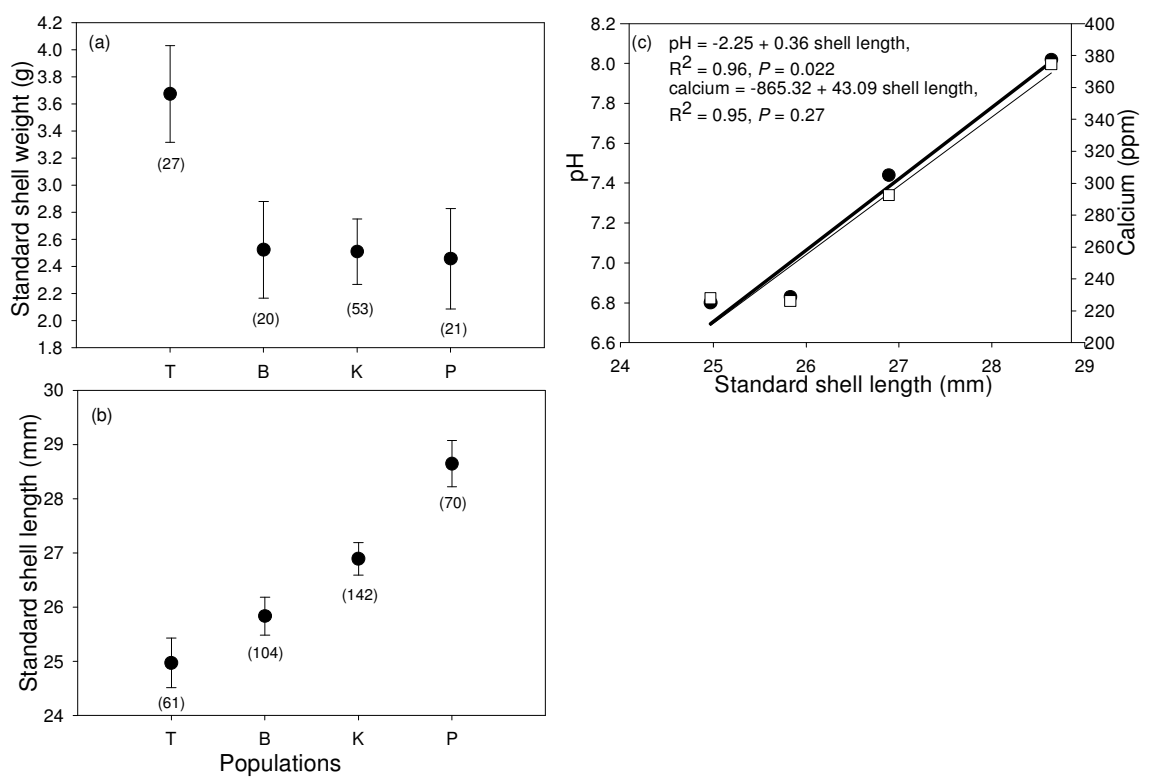

30 
Fig.6
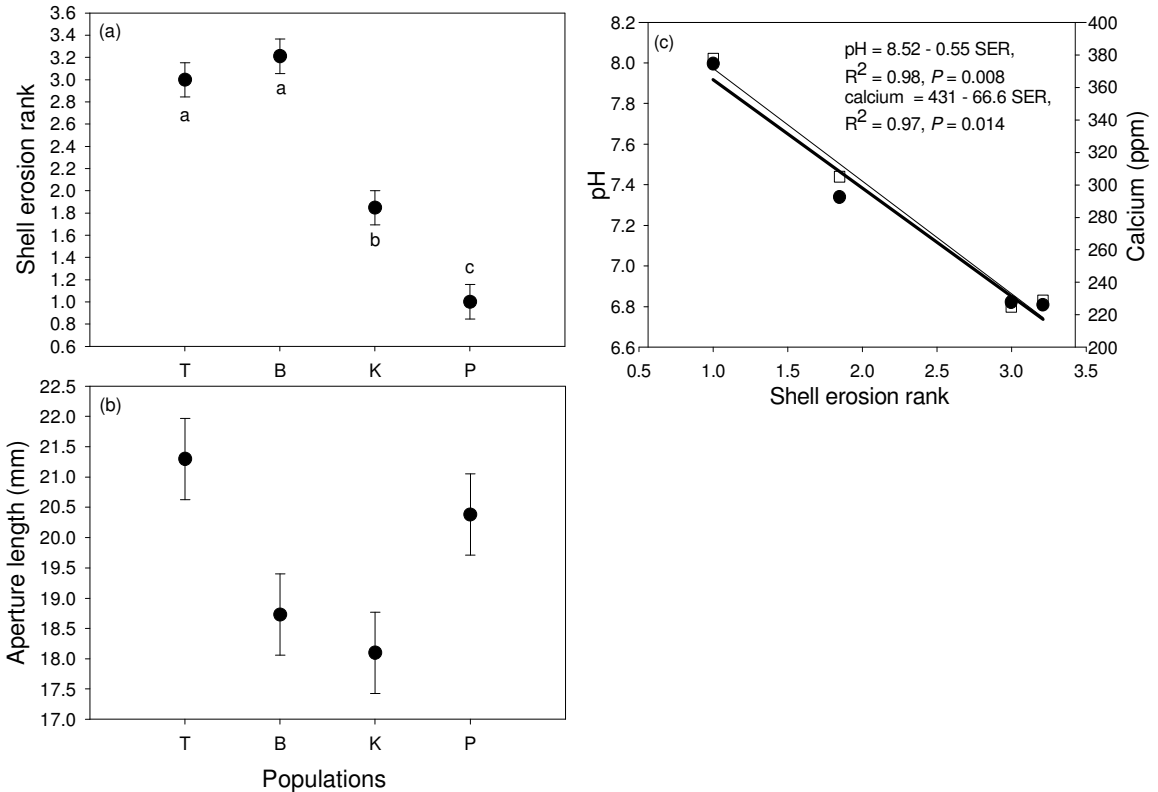